\title{
PERENCANAAN KOMUNIKASI MATAHARI KECIL SEBAGAI ORGANISASI NON-PROFIT DALAM MENDAPATKAN DONASI
}

\author{
Rizkia Dinanti ${ }^{1}$, Rah Utami Nugrahani ${ }^{2}$ \\ ${ }^{1}$ Program Studi Ilmu Komunikasi Fakultas Komunikasi dan Bisnis, Universitas Telkom \\ Email:kiaadinanti@gmail.com \\ ${ }^{2}$ Program Studi Ilmu Komunikasi Fakultas Komunikasi dan Bisnis, Universitas Telkom \\ Email:sayahani@gmail.com
}

\begin{abstract}
Communication planning is one of the most important aspects of achieving goals within a company. In a non-profit organization, donations are urgently needed for the organization's sustenance. Mataharikecil, with a "Spreading goodness" tagline is a non-profit organization meant to spread good to street children with a social background of preaffluent families in order to further education. This research title's is Marketing Communication Strategy as a non-profit organization for donations. This research was find out how Mataharikecil plan can make a such donations that help children who can't continue their schooling further. It used a qualitative method with a descriptive approach and used a constructive paradigm. Data collecting techniques used under observation, interviews, and documentation. This interview is conducted with three internal individuals focused in the small solar donation to explain the communication planning. The resultof this research is what kindof strategy Matahari kecil uses to get donations
\end{abstract}

Keywords: Communication planning, organization, donation

\begin{abstract}
ABSTRAK
Perencanaan komunikasi merupakan salah satu aspek penting sebagai upaya tercapainya tujuan didalam suatu perusahaan. Dalam sebuah organisasi non-profit, donasi sangatlah dibutuhkan demi kelangsungan dari organisasi tersebut. Mataharikecil, dengan tagline "Spreading Goodness", merupakan organisasi non-profit yang bertujuan untuk menyebarkan kebaikan kepada anak-anak jalanan dengan latar belakang keluarga prasejahtera agar bisa melanjutkan pendidikan ketingkat selanjutnya. Penelitian ini berjudul Perencanaan Komunikasi Mataharikecil Sebagai Organisasi Nonprofit Dalam Mendapatkan Donasi. Penelitian ini bertujuan untuk mengetahui bagaimana perencanaan yang dilakukan Mataharikecil bisa mendapatkan donasi sehingga membantu anak-anak yang tidak bisa melanjutkan sekolah ke jenjang selanjutnya. Penelitian ini menggunakan metode kualitatif dengan pendekatan deskriptif dan menggunakan paradigma konstruktivistik. Teknik pengumpulan data yang digunakan dengan cara observasi, wawancara, dan dokumentasi. Wawancara ini dilaksanakan dengan tiga orang internal yang fokus di dalam bidang donasi Mataharikecil agar bisa menjelaskan perencanaan komunikasi yang dilakukan. Hasil dari penelitian ini adalah mengetahui apa perencanaan yang diterapkan Mataharikecil untuk mendapatkan donasi.
\end{abstract}

Katakunci: Perencanaan Komunikasi, Organisasi, Donasi 


\section{PENDAHULUAN}

Di masa era digital dan teknologi yang sangat berkembang pesat, ketatnya persaingan bidang pendidikan pun akan terus meningkat. Dengan kondisi seperti ini, Indonesia juga harus menjaga pelajar agar terus tetap meningkatkan ilmu pengetahuan yang dimiliki. Pendidikan merupakan salah satu fondasi dari kesejahteraan masyarakat di Indonesia. Indonesia juga merupakan salah satu negara berkembang yang dimana tingkat pendidikannya juga sedang berkembang. Indonesia memiliki tujuan dalam meningkatkan pendidikan yaitu bagaimana masyarakat bisa termotivasi agar bersaing meningkatkan wawasan dan pengetahuan tanpa adanya kendala.

Menurut H. Fuad Ihsan (2005: 1), pendidikan adalah bagaimana manusia berusaha untuk menumbuhkan dan mengembangkan potensi yang ada didalam jasmani atau rohani sesuai dengan nilai yang ada di kebudayaan masyarakat. Usaha yang dimaksud adalah bagaimana masyarakat menanam dan mengembangkan nilai-nilai dan norma-norma yang ada agar bisa diberikan kepada generasi mendatang untuk menjadikan landasan didalam proses pendidikan. Pada kenyataanya, beberapa provinsi di Indonesia mendapati hambatan untuk melanjutkan tingkat pendidikan selanjutnya dengan alasan latar belakang keluarga kurang mampu. Permasalahan yang dihadapi adalah bagaimana menyejahterakan anak-anak pelajar yang tidak bisa melanjutkan pendidikan dijenjang selanjutnya.

Dari Publikasi Data Kemendikbud pada tahun 2017/2018, Provinsi Jawa Barat menempati urutan kedua dalam jumlah anak yang putus sekolah. Berdasarkan data tersebut bisa dilihat bahwa anak yang putus sekolah dimulai dari tingkat sekolah dasar yang tidak bisa melanjutkan ke jenjang SMP dengan kendala nilai akhir kecil tidak bisa masuk ke SMP Negeri dan tidak mempunyai biaya untuk masuk ke SMP swasta.

Dari kondisi tersebut, terdapat banyaknya peluang bagi komunitas atau organisasi sosial di luar institusi resmi baik pihak pemerintah atau bukan pemerintah untuk dapat memberikan tindakan berupa bantuan agar bisa membantu meningkatkan fasilitas pendidikan. Terdapat beberapa organisasi sosial-pendidikan nonprofit mempunyai kepedulian terhadap masalah pendidikan di Indonesia. Mataharikecil merupakan organisasi sosial-pendidikan non-profit yang berdiri pada 16 April 2016. Organisasi ini mengutamakan generasi muda untuk menyebarkan kebaikan melalui bidang sosial pendidikan. Organisasi ini didirikan oleh tiga orang, yaitu Yasser M. Saiful, Amar Shidiq, dan Rafi Hidayat dengan tujuan dapat membantu anak-anak keluarga prasejahtera dan latar belakang keluarga ekonomi rendah. Mataharikecil melihat masalah sosial dimana ada beberapa orang anak kurang mampu yang tidak bisa melanjutkan sekolah ke jenjang menegah pertama dikarenakan keluarga yang tidak mampu. Berbeda dengan organisasi sosial-pendidikan yang lain, Mataharikecil memfasilitasi anak-anak bersekolah untuk kondisi yang kurang mampu untuk melanjutkan ke jenjang pendidikan menengah pertama dengan tujuan mengurangi jumlah anak yang putus sekolah. Untuk sementara waktu Tim Mataharikecil memutuskan untuk membuka sekolah terbuka tingkat SMP terlebih dahulu 
dikarenakan melihat dari kondisi nyata disekitar daerah Parakan Saat adalah usia dari anak-anak tersebut berkisar usia 11 sampai 15 tahun yang berada terdekat dengan Gedung Serbaguna Gading Regency yaitu daerah Parakan Saat, Bandung. Pada Oktober 2018, SMP Terbuka Mataharikecil kembali bergabung menginduk kembali pada SMP Terbuka Firdaus dengan alasan bahwa infrastruktur di Gading Regency sedang dilakukan pengalihan.

Berdasarkan data jumlah anak yang diperoleh, penambahan siswa dari tahun ke tahun mengalami peningkatan. Alasan dari pemilihan Mataharikecil sebagai bahan penelitian karena Mataharikecil berbeda dengan organisasi yang lain, beberapa lembaga pendidikan yang diadakan oleh organisasi lain adalah berupa kegiatan belajar tambahan seperti les dan bidang keterampilan, sedangkan Mataharikecil menaungi dan menjadi penopang utama Sekolah Terbuka Gading. Sekolah yang dinaungi sama dengan sekolah negeri ataupun swasta lainnya, tetapi di Sekolah Terbuka Gading tidak dipungut biaya sama sekali dari awal pendaftaran hingga kelulusan

Organisasi sosial yang memiliki beberapa persamaan diantaranya adalah Kakak Asuh dan Teman Tanpa Batas Bandung, mereka merupakan organisasi yang memiliki fokus kepada kondisi sosial dan pendidikan dengan status non-profit organizasation. Dengan status organisasi yang tidak memiliki keuntungan tetap, organisasi tersebut juga mempunyai perencanaan komunikasi tersendiri untuk mendapatkan dana seperti berjualan, kegiatan kewirausahaan, dan terkadang buka donasi atau mencari donatur. Mataharikecil memiliki visi yaitu mengurangi jumlah anak putus sekolah di
Indonesia, meningkatkan kualitas pendidikan di Indonesia dan memiliki misi yaitu membantu anak-anak di Indonesia yang kurang mampu untuk mendapatkan kesempatan pendidikan yang layak, membantu anak-anak Indonesia untuk menemukan passion dan cita-citanya, bekerja sama dengan komunitas sosial di Indonesia untuk mengembangkan programprogram Mataharikecil

Berdasarkan dari visi dan misi dari Mataharikecil, Tim Mataharikecil mendukung dan menjadi fasilitator utama dengan segala upaya, dari mulai sumber daya manusia, infrastruktur, dana, dan juga termasuk tim pengajar yang akan membantu berjalannya kegiatan belajar mengajar disekolah terbuka. Tim pengajar yang ada di sekolah terbuka Mataharikecil merupakan sukarelawan yang dilakukan melalui rekruitasi pada setiap pergantian semester dengan target yaitu mahasiswa-mahasiswi yang berdomisili di Bandung. Mataharikecil sebagai organisasi sosial-pendidikan non-profit mendapatkan donasi pendapatan dengan usaha menggunakan pendekatan komunikasi pemasaran. Berdasarkan hasil wawancara dengan Kak Amar Shiddiq selaku ketua dari Mataharikecil Bandung, terdapat beberapa perencanaan yang dilakukan untuk mendapatkan donasi. Pertama, dengan cara berinteraksi dengan masyarakat yaitu dengan berkunjung langsung ke rumah warga untuk melihat kondisi keadaan tempat tinggal mereka dan juga memastikan bagaimana lingkungan pergaulan mereka. Kedua, melakukan promosi baik menggunakan media ataupun strategy word of mouth. Ketiga, merekruitasi tim sukarelawan untuk menunjang sumber daya manusia sebagai pengajar, lalu 
segala usaha donasi yang dilakukan berupa bisnis, mitra bisnis, acara sosial, donatur, dan CSR. Dari lima jenis usaha yang dilakukan, kegiatan yang paling efektif dan efisien adalah kegiatan donasi dimana kegiatan ini dilakukan oleh pihak Mataharikecil kepada donatur. Dari wawancara yang dilakukan dengan Kak Tesar selaku koordinator sociopreneur periode 20172018, pada pertama kali kegiatan donator ini dilakukan kepada internal Mataharikecil terlebih dahulu dan kemudian pihak eksternal dengan alasan donatur berdonasi adalah karena untuk pembersih atau penyucian harta pendapatan yang mereka peroleh dan juga beberapa individu menyadari dan alasan internal adalah mereka melihat bagaimana ada pihak yang benar-benar membutuhkan karena mereka tau kegiatan yang dilakukan oleh pihak Mataharikecil dan dana yang disalurkan terarah dengan jelas.

Untuk bagian dari mitra bisnis, bisnis, CSR, dan acara sosial tidak terlalu efektif dan efisien karena terdapat masalah waktu dan keuntungan yang lebih kecil dibandingkan dengan donatur. Bentuk dari kegiatan donatur tersebut dilakukan dengan cara langsung. Divisi yang menjalankan bagian usaha donasi di Mataharikecil adalah divisi social enterpreneurship atau yang disingkat dengan Sociopreneur setiap dari bagian sub divisinya mempunyai penanggung jawab agar tercapainya target dana yang diinginkan. Hasil dari kegiatan tersebut digunakan untuk memfasilitasi anak-anak dari mulai ruang belajar, seragam, buku-buku, dan perlengkapan untuk kegiatan ekstrakulikuler di sekolah. Peneliti melihat bahwa Mataharikecil bisa mendapatkan donasi dari beberapa sumber dengan melakukan kerjasama agar terpenuhinya kebutuhan siswasiswi di SMP Terbuka Gading. Berdasarkan dari latar belakang mengenai bagaimana Mataharikecil mendapatkan donasi, maka dalam hal ini peneliti ingin mengambil penelitian dengan judul "Perencanaan Komunikasi Mataharikecil Sebagai Organisasi Non-Profit dalam Mendapatkan Donasi”

\section{Komunikasi}

Menurut Deddy Mulyana (2004:41), Communis berasal dari kata bahasa Latin yang miliki arti "sama". Communico, communicae adalah "membuat sama". Komunikasi merupakan asal dari bahasa Latin yang lain dan serupa. Sedangkan komunikasi menyarankan, bagaimana suatu pikiran atau makna pesan diyakini secara sama. Komunikasi yang berasal dari bahasa Latin, communication berarti sama, yang dimaksud adalah mempunyai makna yang sama (Onong Uchjana Effendy, 2000:9) Menurut Anwar Arifin (1988:17), komunikasi adalah konsep yang memiliki banyak makna. Makna di dalam komunikasi bisa dibedakan berdasarkan arti komunikasi dalam proses sosial. Makna sosial disini memiliki arti dimana ilmuan sosial meneliti dengan menggunakan cara komunikasi umum yang menyudutkan di kegiatan manusia dan keterkaitan antara pesan dan perilaku.

Di dalam komunikasi, terdapat komponen penting, salah satunya yaitu menurut Laswell (1960), terdapat enam komponen-komponen komunikasi, yaitu Komunikator (who atau sender), Pesan (says what atau message), Saluran (channel), Penerima (to whom atau receiver), Umpan balik (feedback), Aturan 
(protocol). komponen tersebut biasa disingkat menjadi "who says what in which channel to whom with what effects".

Dari beberapa rangkuman teori komunikasi di atas, dapat disimpulkan bahwa komunikasi merupakan suatu cara bagaimana seseorang ingin menyampaikan maksud atau pesan kepada khalayak berupa informasi atau pendapat secara langsung atau tidak langsung demi mencapai tujuan yang ingin dicapai kepada penerima pesan dan mengharapkan adanya pesan balik dari penerima dengan melibatkan segala komponen penting di dalam komunikasi, sehingga terjadinya komunikasi dua arah.

Mataharikecil berkomunikasi dengan tujuan menyampaikan pesan kepada khalayak berupa informasi dan pendapat kepada khalayak yang terlibat secara langsung ataupun tidak langsung agar tujuan dari maksud Mataharikecil bisa diterima dan mendapat respon dari khalayak. Komponen di Mataharikecil yang terlibat adalah komunikator yaitu pihak internal atau tim dari Mataharikecil sendiri, pesan yaitu informasi, berita, atau pendapat yang ingin disampaikan. Saluran berupa alat yang digunakan untuk menyampaikan pesan tersebut. Penerima merupakan khalayak yang diberikan pesan dan umpan balik adalah respon yang diberikan khalayak kepada tim Mataharikecil dengan aturan yang sudah ditetapkan.

\section{Perencanaan}

Menurut Cangara (2014: 24), perencanaan adalah segala cara yang telah dipikirkan dan ditentukan dengan pasti lalu dilakukan dikemudian hari dengan tujuan yang ingin dicapai. Perencanaan juga adalah langkah dasar yang akan digunakan untuk memilih tujuan dan dijabarkan bagaimana cara akan mendapatkannya (Kusmiadi, 1995). Menurut Harjanto (2008), perencanaan bersangkutan denganmenentukan apayangakan dilaksanakan. Karena dengan urutannya perencanaan lalu ke pelaksanaan, maka perencanaan adalah suatu langkah yang dapat menentukan arah dan mengidentifikasi apa yang diinginkan dengan alur yang efektif dan efisien.

Berdasarkan pengertian diatas, perencanaan merupakan rancangan yang akan diterapkan untuk mendapatkan sesuatu dan tujuan yang sesuai dengan apa yang telah disusun sebelumnya. Mataharikecil melakukan perencanaan untuk mendapatkan tujuan yaitu mendapatkan donasi. Rencana yang sudah diatur untuk mencari donasi sudah ditetapkan agar pada saat pelaksanaan kegiatan mencari donator bisa berjalan dengan efektif dan efisien.

Berdasarkan wawancara yang telah dilakukan dengan pihak Mataharikecil, perencanaan yang disusun serupa dengan pendekatan dengan Model Perencanaan Komunikasi 5 Langkah (Cangara 2013), yaitu:

1. Penelitian (Research) Riset atau penelitian digunakan agar dapat memahami masalah apa yang ada di suatu perushaan tersebut.

2. Perencanaan(Plan) Perencanaan digunakan setelah mengetahui apa hasil dari riset sebelumnya agar bisa merencanakan apa yang akan dilakukan oleh perusahaan.

3. Pelaksanaan (Execute) Pelaksanaan atau tindakan merupakan kegiatan yang mewujudkan dari perencanaan komunikasi yang ditetapkan sebelumnya

4. Pengukuran/Evaluasi (Measure) Evaluasi 
merupakan tahapan untuk melihat hasil dari pelaksanaan yang dilakukan. Tahapan evaluasi yang dilakukan adalah bagaimana suatu perusahaan bisa menjalin hubungan komunikasi dengan para konsumen, bagaimana system komunikasi pesan yang disampaikan oleh perusahaan.

5. Pelaporan (Report) Pelaporan merupakan tahapan terakhir dari seluruh kegitan perencanaan yang telah dilakukan. Laporan biasanya berbentuk laporan tulis yang diberikan kepada pimpinan sebagai bahan pembanding dan evaluasi. Dengan hasil laporan tersebut, perusahaan bisa menganalisa bagaimana jalannya rencana yang dilakukan. Apabila didalam suatu laporan tersebut didapatkan hasilnya baik dan meningkat, maka perencanaan yang dilakukan layak untuk digunakan kedepan dan begitu pula sebaliknya (Cangara, 2013:77)

\section{Public Relations (Humas)}

Menurut J.C Seidel dalam Saoemirat dan Ardianto (2007), Public Relations merupakan prosedur yang dilakukan secara berulang sebagai usaha untuk memperoleh tindakan baik dan tanggapan dari konsumen atau khalayak tantang hal baik di dalam diri. Sedangkan menurut Moore dalam Masykuri (2004: 356) Public Relations adalah ajaran manajemen sosial yang bersifat bijaksana dan pelaksanaanya menggunakan penjelasan tentang kejadian atau peristiwa dengan komunikasi dua arah antara publik dan pribadi untuk mendapatkan suatu hal yang baik. Di dalam Mataharikecil, Public Relations digunakan sebagai salah satu alat dalam mencapai tujuan yaitu pendanaan atau donasi yang bisa membantu tim social enterpreneur dalam mendapatkan target. Mataharikecil melakukan kegiatan public relations kepada masyarakat agar bisa terciptanya pengetahuan yang baik kepada masyarakat.

\section{METODE PENELITIAN}

Di dalam penelitian ini, penulis menggunakan paradigma konstruktivistik karena mengetahui pemahaman dan membantu mengembangkan proses yang sedang dilakukan dari objek penelitian. Sehingga, pada saat proses penelitian sedang berlangsung, peneliti lebih memahami dan bisa mengembangkan makna dan pemahaman yang terjadi di dalam objek peneliti. Menurut Bogdan dan Biklen (dalam Syamsudin, 2009:175) studi kasus merupakan pengujian secara mendetil dalam sebuah latar, subjek, penyimpanan dokumen atau peristiwa. Studi kasus sebagai pendekatan dilakukan dengan memberikan perhatian lebih dalam suatu fenomena dengan teliti dan detil (Surachman (dalam Syamsudin, 2009: 175)) Alasan peneliti menggunakan metode studi kasus ini karena di dalam penelitian dilakukan secara mendalam dan mengamati bagaimana perencanaan komunikasi Mataharikecil dalam mendapatkan donasi.

\section{HASIL DAN PEMBAHASAN}

Di dalampenelitianini, penelitimelakukan teknik wawancara dengan tiga informan kunci yang dimana informan sepakat dan telah menyetuji dengan penelitian ini. Perencanaan yang dilakukan oleh tim Mataharikecil adalah dengan pendekatan lima langkah (Cangara 
2013), yaitu:

1. Penelitian : internal tim Matahari kecil melakukan riset kecil dengan melihat target pasar dan calon donator yang akan ditujukan

2. Perencanaan : melakukan penyusunan rencana yang akan diterapkan pada tahap selanjutnya. Pada perencanaan ini tim Mataharikecil mendata siapakah calon donator yang akan ditarik dan menyesuaikan persiapan internal Mataharikecil kepada pihak donatut

3. Pelaksanaan : pelaksanaan dilakukan sesuai dengan tahapan rencana agar tindakan dilapangan tersusun dengan sistematis

4. Evaluasi : proses evaluasi bertujuan untuk dapat melihat kembali proses di lapangan dan sebagai bahan pembelajaran apa yang harus dipertahankan untuk kegiatan kedepan

5. Pelaporan : digunakan sebagai data base dan juga dipaparkan kepada seluruh tim Mataharikecil agar adanya trasnparansi data dalam kegiatan mencari donator ini.

Berdasarkan dari hasil wawancara yang dilakukan, peneliti merangkum hasil wawancara kedalam tabel seperti berikut:

Tabel 1 : Penjabaran penelitian

\begin{tabular}{|l|l|}
\hline Pertanyaan & $\begin{array}{l}\text { Apa yang dilakukan tim } \\
\text { Mataharikecil dalam kegiatan untuk } \\
\text { menentukan target donatur? }\end{array}$ \\
\hline Informan 1 & $\begin{array}{l}\text { "....nah biasanya kalo di dalam rapat } \\
\text { itu kita ngelakuin mini riset pasar } \\
\text { gitu" }\end{array}$ \\
\hline Informan 2 & $\begin{array}{l}\text { "Tahap pertama itu biasanya kita } \\
\text { nentuin dulu target pasar kita itu } \\
\text { siapa, cocok ga sama apa yang ingin } \\
\text { kita tawarkan." }\end{array}$ \\
\hline
\end{tabular}

\begin{tabular}{|l|l|}
\hline Informan 3 & \multicolumn{1}{|c|}{ "Kalo dari matcilnya sendiri } \\
& biasanya kita tuh cari-cari tau \\
& $\begin{array}{l}\text { dulu. Kalo bisa dibilang riset-riset } \\
\text { kecilan gitu lah..." }\end{array}$ \\
\hline
\end{tabular}

(sumber: Olahan peneliti)

Tabel 2 : Penjabaran penelitian

\begin{tabular}{|l|l|}
\hline Pertanyaan & $\begin{array}{l}\text { Hal apa yang dilakukan setelah } \\
\text { mendapatkan data dari riset } \\
\text { Sebelumnya }\end{array}$ \\
\hline Informan 1 & $\begin{array}{l}\text { "ngebahas donaturnya mau siapa } \\
\text { aja, terus cara kita ke donaturnya } \\
\text { gimana, ngirim proposalnya } \\
\text { gimana," }\end{array}$ \\
\hline Informan 2 & $\begin{array}{l}\text { "kita } \\
\text { nge-planning apa yang harus kita } \\
\text { buat dan cocok ga cara yang kita } \\
\text { lakukan.." }\end{array}$ \\
\hline Informan 3 & $\begin{array}{l}\text { "ditentukan siapa yang maju, } \\
\text { dibuat timeline, kapan kita harus } \\
\text { jalan,kapan kita harus capai target" }\end{array}$ \\
\hline
\end{tabular}

(sumber: Olahan peneliti)

Tabel 3 : Penjabaran penelitian

\begin{tabular}{|l|l|}
\hline Pertanyaan & $\begin{array}{l}\text { Apa yang dilakukan dalam proses } \\
\text { pelaksanaan ini? }\end{array}$ \\
\hline Informan 1 & $\begin{array}{l}\text { "kita bisa langsung ngedatengin } \\
\text { donatur itu masing-masing" }\end{array}$ \\
\hline Informan 2 & $\begin{array}{l}\text { "Biasanya kita presentasi gitu } \\
\text { sih atapun ya ngobro langsung } \\
\text { ngejelasin kita tujuannya, } \\
\text { bergeraknya dibidang apa, " }\end{array}$ \\
\hline Informan 3 & $\begin{array}{l}\text { "kita langsung explain, tujuan kita } \\
\text { apa pertama itu. Kenalin diri kita, } \\
\text { terus ajuin proposal, kita explain } \\
\text { apa nih tujuan kita gitu kan. } \\
\text { Menerangkan kalo kita cari donasi" }\end{array}$ \\
\hline
\end{tabular}

(sumber: Olahan peneliti) 
Tabel 4 : Penjabaran penelitian

\begin{tabular}{|l|l|}
\hline Pertanyaan & $\begin{array}{l}\text { Apa tujuan dari pelaksanaan evaluasi } \\
\text { kegiatan ini? }\end{array}$ \\
\hline Informan 1 & $\begin{array}{l}\text { “....kesulitan dilapangannya itu apa, } \\
\text { pahamjuga tahapan selanjutnya kita } \\
\text { harus kayak gimana, apasih yang } \\
\text { dibutuhin donatur ...." }\end{array}$ \\
\hline Informan 2 & $\begin{array}{l}\text { “..ngeliat plus minus nya dari } \\
\text { kegiatan kita tuh gimana dan acuan } \\
\text { kita biar lebih baik lagi..." }\end{array}$ \\
\hline Informan 3 & $\begin{array}{l}\text { "...evaluasi apa yang minus apa } \\
\text { yang harus dipertahankan dari cari } \\
\text { donasi ini.." }\end{array}$ \\
\hline
\end{tabular}

(sumber: Olahan peneliti)

Tabel 5 : Penjabaran penelitian

\begin{tabular}{|c|c|}
\hline Pertanyaan 1 & $\begin{array}{l}\text { Apa saja yang dilakukan saat } \\
\text { pelaporan? }\end{array}$ \\
\hline Informan 1 & $\begin{array}{l}\text { “.... ada diskusi lagi kayak } \\
\text { presentasi akhir lagi lah buat } \\
\text { ngejelasin dari awal sampe akhir } \\
\text { pelaksanaannya kayak apa...” }\end{array}$ \\
\hline Informan 2 & "dateng ngejelasin, diskusi". \\
\hline Informan 3 & $\begin{array}{l}\text {. "untuk ngelaporin dari pansus } \\
\text { ke koor ke pansus ke matcil } \\
\text { semuanya... }\end{array}$ \\
\hline Pertanyaan 2 & $\begin{array}{l}\text { Seperti apa bentuk laporan yang } \\
\text { disajikan? }\end{array}$ \\
\hline Informan 1 & $\begin{array}{l}\text { "...bikin naskah word kayak print- } \\
\text { out nya juga gitu, terus kita bikin } \\
\text { pptnya” }\end{array}$ \\
\hline Informan 2 & "Biasanya word, ppt, excel..." \\
\hline Informan 3 & $\begin{array}{l}\text { "...ada yang berbentuk ppt, ada } \\
\text { yang word gitu..." }\end{array}$ \\
\hline Pertanyaan 3 & Apa tujuannya pelaporan? \\
\hline Informan 1 & $\begin{array}{l}\text { “...profesionalitas kita kayak } \\
\text { tanggung jawabnya kita terhadap } \\
\text { si donatur sama atasankita baik } \\
\text { dipihak socio ataupun matcil. Itu } \\
\text { juga sebagai arsip sih bagi kita...” }\end{array}$ \\
\hline
\end{tabular}

\begin{tabular}{|l|l|}
\hline Informan 2 & $\begin{array}{l}\text { "Ngeliat kinerja kita, diskusi sama } \\
\text { pansus-pansus kendala apa dan } \\
\text { cari solusi buat selesein masalah" }\end{array}$ \\
\hline Informan 3 & $\begin{array}{l}\text { "...buat acuan kita kalo ada acara } \\
\text { kedepannya apa ya buat misalnya } \\
\text { siapa tau itu perusahaan mau } \\
\text { kerjasama sama matcil ..." }\end{array}$ \\
\hline
\end{tabular}

(sumber: Olahan peneliti)

Mataharikecil melakukan kegiatan awal hingga tahapan akhir yang sesuai dengan perencanaan yang telah ada sejak awal kegiatan mancari donasi dilakukan. Langkah awal untuk menentukan donatur yang akan dipilih diantaranya adalah donatur yang aware dan peduli terhadap sosial pendidikan, tidak terpaku kepada perusahaan atau organisasi besar. Lalu mendata apa yang akan dilakukan dan dipersiapkan kepada donatur, lalu Mataharikecil mulai menjelaskan dan memaparkan apa tujuan mereka kepada donatur. Setelah memaparkan kepada donatur, pihak

Berdasarkan hasil penelitian yang dilakukan oleh peneliti dengan menggunakan analisis perencanaan komunikasi Mataharikecil dalam mendapatkan donasi, maka peneliti dapat menarik kesimpulan sebagai berikut:

1. Perencanaan komunikasi yang dilakukan oleh Mataharikecil dalam mendapatkan donasi dapat dibagi menjadi proses:

a) Penelitian: menentukan bagaimana tahapan awal tim Mataharikecil dapat mengambil langkah untuk mendapatkan donasi dari donatur.

b) Perencanaan: pmenyusun konsep yang akan diterapkan dalam mencari donasi. Mengatur langkah atau tahapan yang akan diterapkan. Pengelolaan bagian 
tim agar bisa mematuhi tanggung jawab.

c) Pelaksanaan: Mataharikecil berhasil mencapai tujuan dari mendapatkan donasi dimana dengan menggunakan tahapan yang sistematis dalam penerapan dan pelaksanaan kegiatan itu sendiri.

d) Evaluasi: terdapat evaluasi internal yang berupa evaluasi kinerja SDM dan evaluasi eksternal yang berupa feedback dari donatur.

e) Laporan: dari semua tahapan, laporan diperlukan sebagai data dan transparansi kepada semua anggota Mataharikecil dan juga agar menjadi bahan acuan untuk kegiatan yang lainnya.

2. Perencanaan yang diterapkan telah sesuai dengan apa yang telah dilakukan oleh tim Mataharikecil dalam mendapatkan donasi.

\section{PENUTUP}

Setelah melakukan penelitian dan melihat hasil yang didapatkan dari penelitian ini, maka saran yang dapat peneliti berikan adalah:

\section{Saran Akademis}

a. Sebagai acuan peneliti selanjutnya tentang perencanaan komunikasi serta bisa mengangkat perencanaan komunikasi dengan pendekatan yang lain

b. Disarankan kepada peneliti-peneliti lainnya agar bisa memperbanyak penelitian yang berkaitan dengan perencanaan komunikasi dalam mendapatkan donasi agar organisasi lainnya bisa lebih fokus dan teliti untuk menyampaikan pesan kepada targetnya.

\section{Saran Praktis}

Peneliti menyarankan agar pihak eksternal diperbolehkan untuk membantu dengan tujuan menambahkan jumlah SDM yang kurang dan memperbanyak nominal jumlah donasi yang diberikan dari banyak donatur.

\section{DAFTAR PUSTAKA}

Anwar, Arifin. 1988. Ilmu Komunikasi Suatu Pengantar Ringkas. Jakarta: Rajawali Press

Cangara, H. Hafied. 2013. Perencanaan dan Strategi Komunikasi. Jakarta: PT. Raja Grafindo Persada

Cangara, Hafied. 2014. Pengantar Ilmu Komunikasi. Jakarta. PT Raja Grafindo Persada

Effendy, Onong Uchjana. 2003. Ilmu, Teori, dan Filsafat Komunikasi. Bandung: Citra Aditya Bakti. Rajawali Pers

Fuad Ihsan. 2005. Dasar-dasar Pendidikan. Jakarta: PT Rineka Cipta.

Lasswell, Harold. 1960. The Structure and Function of Communication in Society, Urbana: University of Illinois Press.

Mulyana, Deddy. 2004. Metodologi Penelitian Kualitatif. Bandung: PT Remaja Rosdakarya.

Soemirat, Soleh dan Elvinaro Ardianto. 2004. Dasar-dasar Public relation. Bandung: PT Remaja Rosdakarya

Syamsuddin, 2009. Manajemen Keuangan Perusahaan. Penerbit PT. Raja Grafindo Persada. Jakarta 
130 | Komunikasi, Vol. XIII No. 02, September 2019: 121-130 